$\pm N / E$

Global Journals Inc.

की

\title{
Effect of Scouring and Bleaching Agents on Whiteness Index and Bursting Strength of Cotton Knitted Fabric
}

\author{
By MD. Tofazzal Hossain, Alimran Hossain, Palash Kumar Saha \\ \& MD. Zahangir Alam \\ Northern University
}

Abstract- This paper shows the effect of different bleaching agent on whiteness index and bursting strength of the cotton knitted fabric. Bleaching process uses three types of bleaching agents namely hydrogen peroxide $\left(\mathrm{H}_{2} \mathrm{O}_{2}\right)$, sodium hypochlorite $(\mathrm{NaOCl})$ and calcium hypochlorite $\mathrm{Ca}(\mathrm{OCl})_{2}$ with varying their concentration and these are $1.5 \mathrm{~g} / \mathrm{l}, 2.5 \mathrm{~g} / \mathrm{l}, 3.5 \mathrm{~g} / \mathrm{l}, 4.5$ $\mathrm{g} / \mathrm{l}$, and $5.5 \mathrm{~g} / \mathrm{l}$. In the same time, scouring agent was caustic soda, and its concentration for all the bleaching agents was same. It is obvious that with the increase of bleaching agent concentration, whiteness index increases, and bursting strength reduces.

Keywords: bleaching agents, cotton knitted fabric, whiteness index, bursting strength, concentration.

GJRE-J Classification: FOR Code: 860499

Strictly as per the compliance and regulations of:

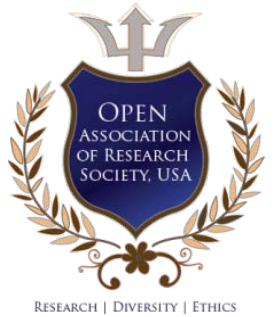

(c) 2019. MD. Tofazzal Hossain, Alimran Hossain, Palash Kumar Saha \& MD. Zahangir Alam. This is a research/review paper, distributed under the terms of the Creative Commons Attribution-Noncommercial 3.0 Unported License http://creative commons.org/licenses/by-nc/3.0/), permitting all non commercial use, distribution, and reproduction in any medium, provided the original work is properly cited. 


\title{
Effect of Scouring and Bleaching Agents on Whiteness Index and Bursting Strength of Cotton Knitted Fabric
}

\author{
MD. Tofazzal Hossain ${ }^{\alpha}$, Alimran Hossain ${ }^{\circ}$, Palash Kumar Saha ${ }^{\circ} \&$ MD. Zahangir Alam ${ }^{\omega}$
}

\begin{abstract}
This paper shows the effect of different bleaching agent on whiteness index and bursting strength of the cotton knitted fabric. Bleaching process uses three types of bleaching agents namely hydrogen peroxide $\left(\mathrm{H}_{2} \mathrm{O}_{2}\right)$, sodium hypochlorite $(\mathrm{NaOCl})$ and calcium hypochlorite $\mathrm{Ca}(\mathrm{OCl})_{2}$ with varying their concentration and these are $1.5 \mathrm{~g} / \mathrm{l}, 2.5 \mathrm{~g} / \mathrm{l}$, $3.5 \mathrm{~g} / \mathrm{l}, 4.5 \mathrm{~g} / \mathrm{l}$, and $5.5 \mathrm{~g} / \mathrm{l}$. In the same time, scouring agent was caustic soda, and its concentration for all the bleaching agents was same. It is obvious that with the increase of bleaching agent concentration, whiteness index increases, and bursting strength reduces.
\end{abstract}

Keywords: bleaching agents, cotton knitted fabric, whiteness index, bursting strength, concentration.

\section{InTRODUCTION}

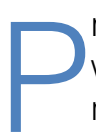
retreatment of textile materials is very important, without pretreatment the coloration of cotton is nearly impossible to get the desired result. For the achievement of optimum whiteness, the removing of natural color from the grey cotton fabric is a must. S. M. F. Kabir et al shows in their study that the whiteness of cotton increases with the use of blue or optical brightening agents [1]. But there may arise some problems in case of further coloration process because blue or optical brightening agents can affect the shade of the dyed fabric.

Generally scouring removes all impurities except the natural coloring matters which have to be broken down by bleaching agent either with an oxidizing or reducing agent. When the color acts upon by reducing agent, there is always the possibility that the oxygen in the air may deoxidize it to its original color [2].

There are different bleaching agents for this purpose; most of them are oxidative. S. Polat et al. shows in their investigation, the amount of hydrogen peroxide has a great effect on the whiteness of cotton knitted fabric [3].

Saravanan et al. study on the bleaching effect of cotton fabrics shows that by using hydrogen peroxide, which is from glucose oxidase enzyme, shows lower whiteness values than the expectation of the commercial processes [4]. Kumbasar et al. investigation on hydrophilicity and whiteness index shows that with the increase of hydrogen peroxide and activator concentration, hydrophilicity and whiteness increase also increase [5]. With the perfect bleaching of cotton fabric, some weight loss of cotton fabric will happen. Abdul and Narendra found that in their study, with the increase in concentration of bleaching agent, whiteness index increases but the weight of material decreases [6]. In the case of weight loss, there may be an effect of bursting strength of cotton fabrics.

For the achievement of optimum whiteness index there may be loss of weight of the cotton fabric, Naser et al. try to optimize bleaching parameters for whiteness index and bursting strength of the knitted cotton fabric, they observe an inverse relation between themselves [7].

\section{il. Materials and Methods}

\section{a) Materials}

100\% cotton knitted single jersey (160 GSM) and hydrogen peroxide $\left(\mathrm{H}_{2} \mathrm{O}_{2}\right)$, sodium hypochlorite $(\mathrm{NaOCl})$ and calcium hypochlorite $\mathrm{Ca}(\mathrm{OCl})_{2}$ were used as bleaching agents and sodium hydroxide as a scouring agent.

b) Work outline

Collection of Grey Fabric
$\downarrow$
Scouring and bleaching
$\downarrow$
Whiteness Test (By Using Spectrophotometer)
$\downarrow$
Bursting strength Test (By Using Bursting Strength
Tester)
$\downarrow$
Result and Discussion

\section{c) Scouring \& Bleaching Recipe}

Different bleaching agents at different concentration were used in this research paper for investigation of whiteness index and bursting strength of $100 \%$ cotton knitted single jersey. 
Table 1: Bleaching by Hydrogen Peroxide $\left(\mathrm{H}_{2} \mathrm{O}_{2}\right)$

\begin{tabular}{|c|c|c|c|c|c|}
\hline Sample No. & Hydrogen Peroxide $\left(\mathrm{H}_{2} \mathrm{O}_{2}\right)$ & Sodium Hydroxide $(\mathrm{NaOH})$ & Temperature & Time & $\mathrm{M}: \mathrm{L}$ \\
\hline 1 & $1.5 \mathrm{~g} / \mathrm{l}$ & $1 \mathrm{~g} / \mathrm{l}$ & \multirow{5}{*}{$98^{\circ} \mathrm{C}$} & \multirow{5}{*}{$30 \mathrm{~min}$} & \multirow{5}{*}{$1: 10$} \\
\hline 2 & $2.5 \mathrm{~g} / \mathrm{l}$ & $2 \mathrm{~g} / \mathrm{l}$ & & & \\
\hline 3 & $3.5 \mathrm{~g} / \mathrm{l}$ & $3 \mathrm{~g} / \mathrm{l}$ & & & \\
\hline 4 & $4.5 \mathrm{~g} / \mathrm{l}$ & $4 \mathrm{~g} / \mathrm{l}$ & & & \\
\hline 5 & $5.5 \mathrm{~g} / \mathrm{l}$ & $5 \mathrm{~g} / \mathrm{l}$ & & & \\
\hline
\end{tabular}

Table 2: Bleaching by Sodium Hypochlorite $\mathrm{NaOCl}$

\begin{tabular}{|c|c|c|c|c|c|}
\hline Sample No. & Sodium Hypochlorite $\mathrm{NaOCl}$ & Sodium Hydroxide $(\mathrm{NaOH})$ & Temperature & Time & M:L \\
\hline 6 & $1.5 \mathrm{~g} / \mathrm{l}$ & $1 \mathrm{~g} / \mathrm{l}$ & \multirow{5}{*}{$60^{\circ} \mathrm{C}$} & \multirow{5}{*}{$50 \mathrm{~min}$} & \multirow{5}{*}{$1: 10$} \\
\hline 7 & $2.5 \mathrm{~g} / \mathrm{l}$ & $2 \mathrm{~g} / \mathrm{l}$ & & & \\
\hline 8 & $3.5 \mathrm{~g} / \mathrm{l}$ & $3 \mathrm{~g} / \mathrm{l}$ & & & \\
\hline 9 & $4.5 \mathrm{~g} / \mathrm{l}$ & $4 \mathrm{~g} / \mathrm{l}$ & & & \\
\hline 10 & $5.5 \mathrm{~g} / \mathrm{l}$ & $5 \mathrm{~g} / \mathrm{l}$ & & & \\
\hline
\end{tabular}

Table 3: Bleaching by Calcium Hypochlorite $\mathrm{Ca}(\mathrm{OCl})_{2}$

\begin{tabular}{|c|c|c|c|c|c|}
\hline Sample No. & Calcium Hypochlorite $\mathrm{Ca}(\mathrm{OCl})_{2}$ & Sodium Hydroxide $(\mathrm{NaOH})$ & Temperature & Time & $M: L$ \\
\hline 11 & 1.5 & $1 \mathrm{~g} / \mathrm{l}$ & \multirow{5}{*}{$60^{\circ} \mathrm{C}$} & \multirow{5}{*}{$50 \mathrm{~min}$} & \multirow{5}{*}{$1: 10$} \\
\hline 12 & 2.5 & $2 \mathrm{~g} / \mathrm{l}$ & & & \\
\hline 13 & 3.5 & $3 \mathrm{~g} / \mathrm{l}$ & & & \\
\hline 14 & 4.5 & $4 \mathrm{~g} / \mathrm{l}$ & & & \\
\hline 15 & 5.5 & $5 \mathrm{~g} / \mathrm{l}$ & & & \\
\hline
\end{tabular}

d) Process curve for Hydrogen Peroxide $\left(\mathrm{H}_{2} \mathrm{O}_{2}\right)$

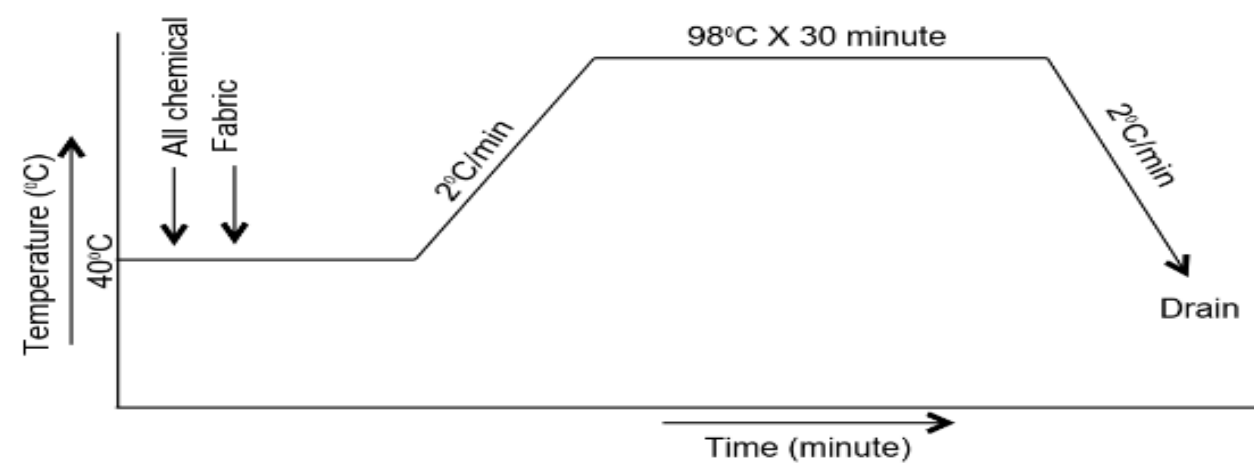

Figure 1: Bleaching process curve for Hydrogen Peroxide $\left(\mathrm{H}_{2} \mathrm{O}_{2}\right)$

e) Process curve for Sodium Hypochlorite(NaOCl)

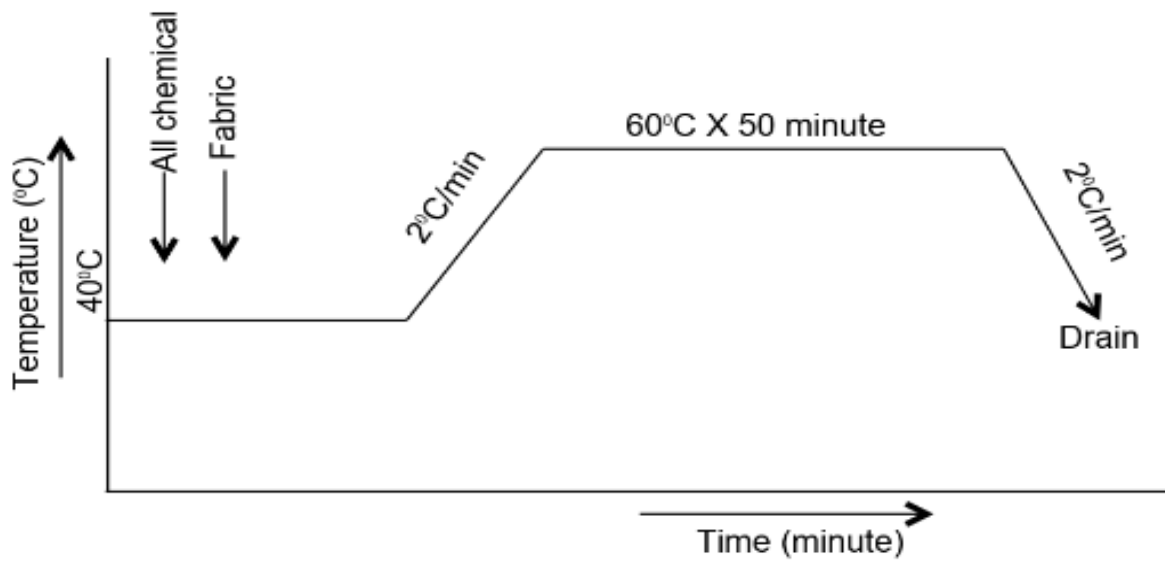

Figure 2: Bleaching Process curve for Sodium Hypochlorite ( $\mathrm{NaOCl}$ ) 
f) Process curve for Calcium Hypo chlorite $\mathrm{Ca}(\mathrm{OCl})_{2}$

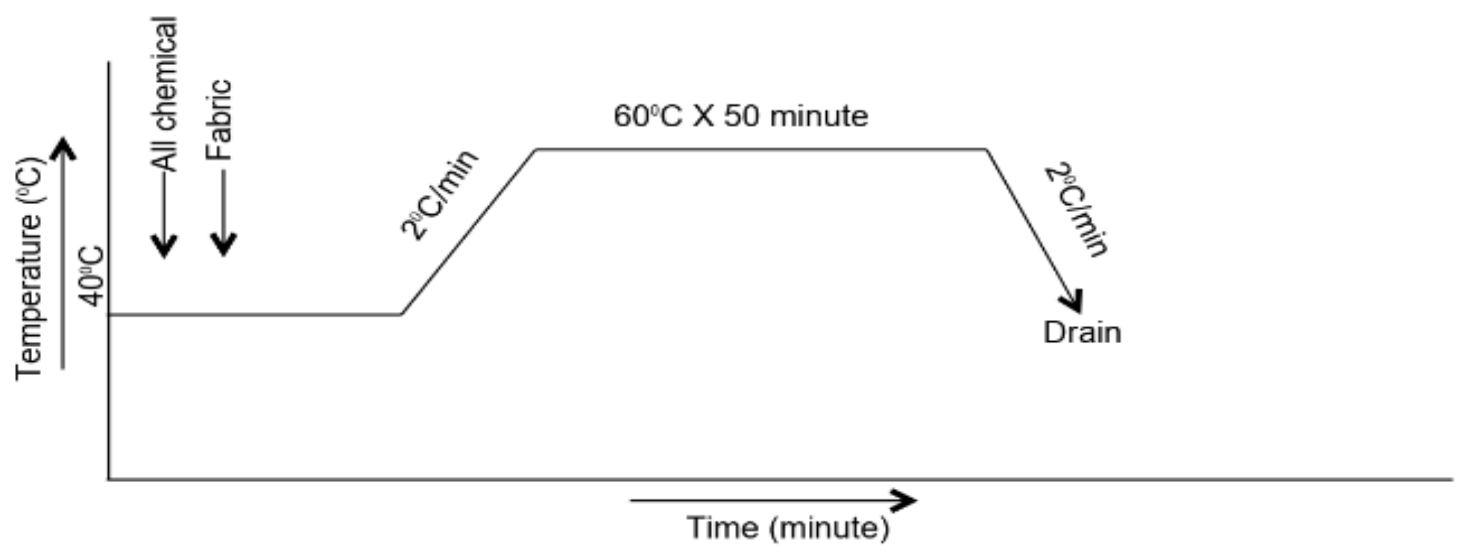

Figure 3: Bleaching Process curve for calcium Hypochlorite $\left(\mathrm{Ca}(\mathrm{OCl})_{2}\right)$

g) Measurement of whiteness Index

Whiteness index of the scoured and bleached sample was determined by the reflectance value of spectrophotometer (Datacolor650) at $10^{\circ}$ observer and D65 illuminant.

h) Measurement of Bursting Strength Test

Pneumatic method (ISO 13938-2: 1999) was used for the determination of bursting strength and bursting properties of the samples [8].

\section{ili. Result \& Discussions}

a) Effect of hydrogen peroxide $\left(\mathrm{H}_{2} \mathrm{O}_{2}\right)$ on whiteness

The whiteness index of the sample increases with the increase of peroxide concentration markedly upto $4.5 \mathrm{~g} / \mathrm{l}$. Further increasing of hydrogen peroxide does not play a significant role in increasing whiteness index, and $4.5 \mathrm{~g} / \mathrm{l}$ is the optimum concentration.

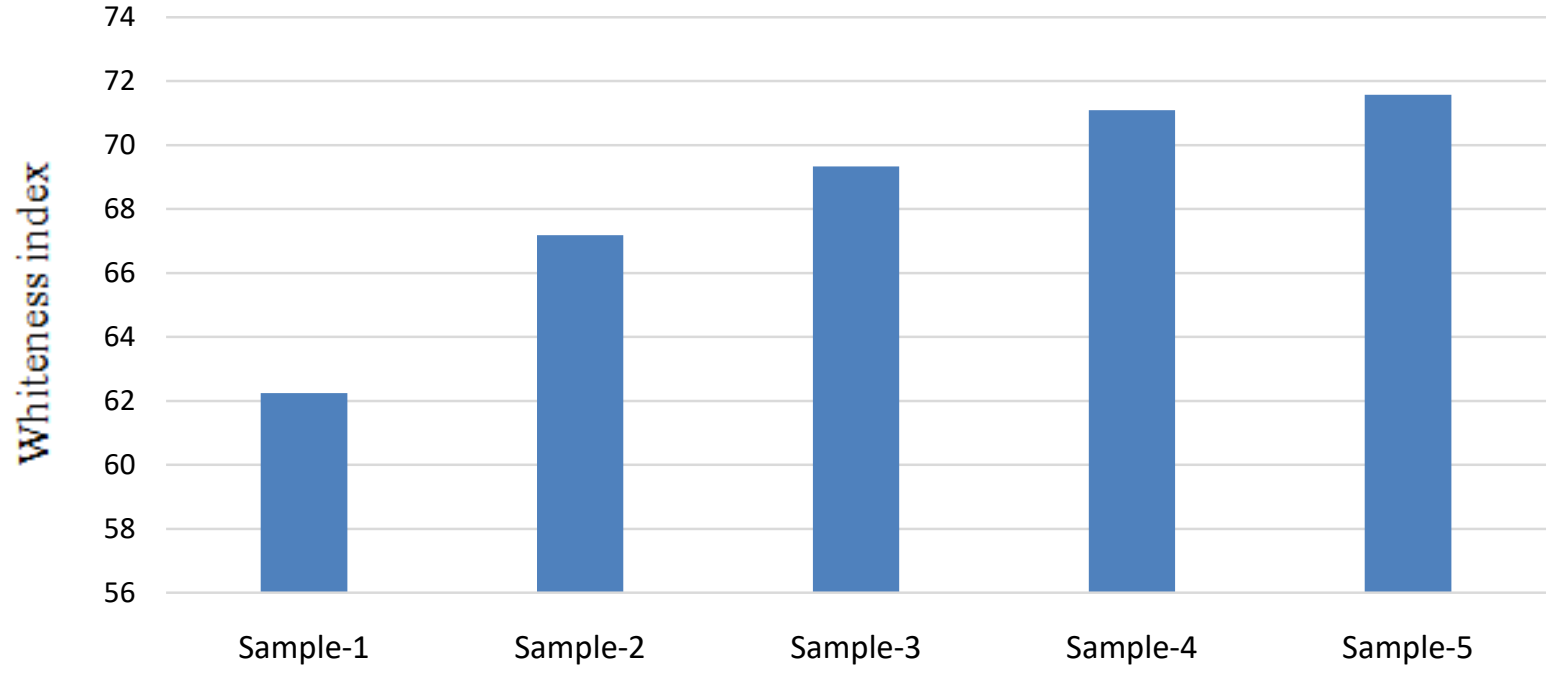

Figure 4: Effect of hydrogen peroxide $\left(\mathrm{H}_{2} \mathrm{O}_{2}\right)$ on whiteness index

b) Effect of hydrogen peroxide $\left(\mathrm{H}_{2} \mathrm{O}_{2}\right)$ on bursting strength

Following graph shows the effect of hydrogen peroxide concentration on the bursting strength and it seems that $3.5 \mathrm{~g} / \mathrm{l}$ has a moderate effect on the strength of the fabric. 


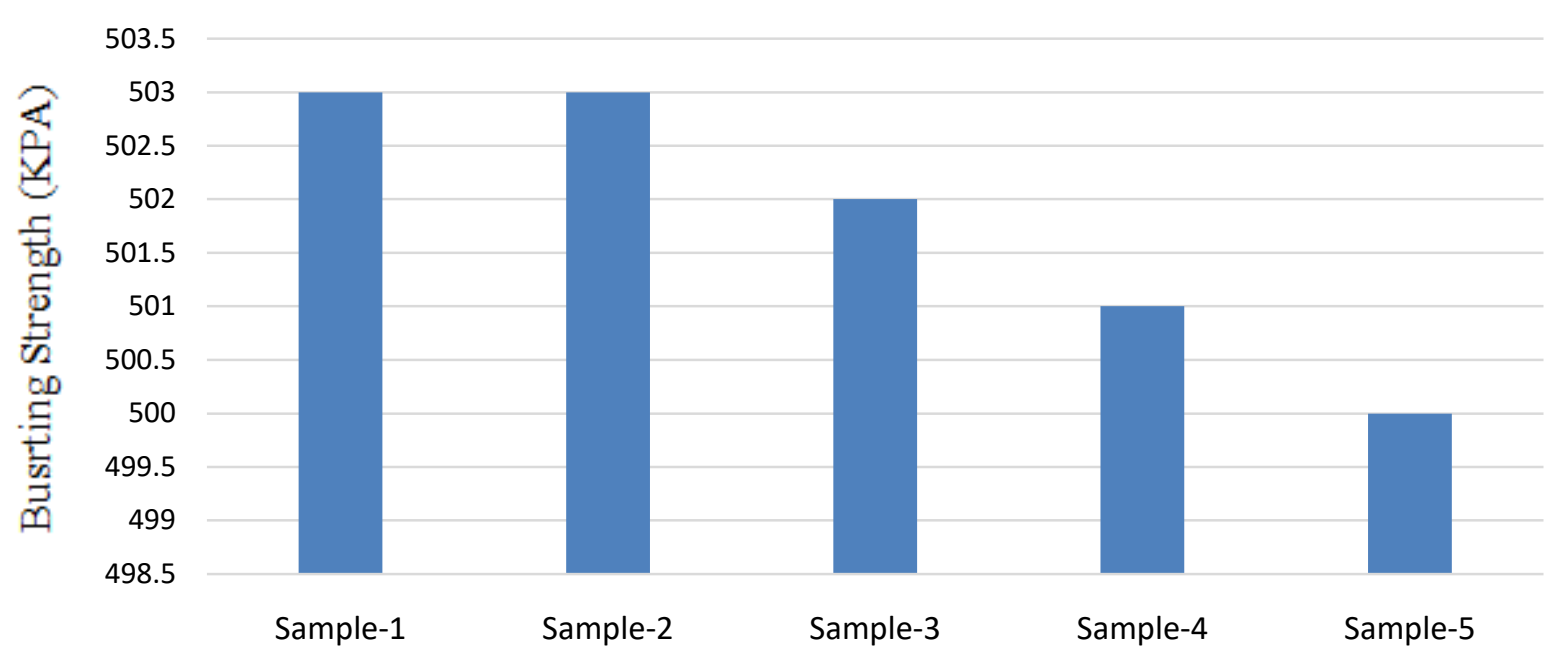

Figure 5: Effect of hydrogen peroxide $\left(\mathrm{H}_{2} \mathrm{O}_{2}\right)$ on bursting strength

c) Effect of Sodium Hypochlorite $(\mathrm{NaOCl})$ on whiteness

From figure 6, it is clear that for increasing concentration of sodium hypochlorite, whiteness index increases.

60

50

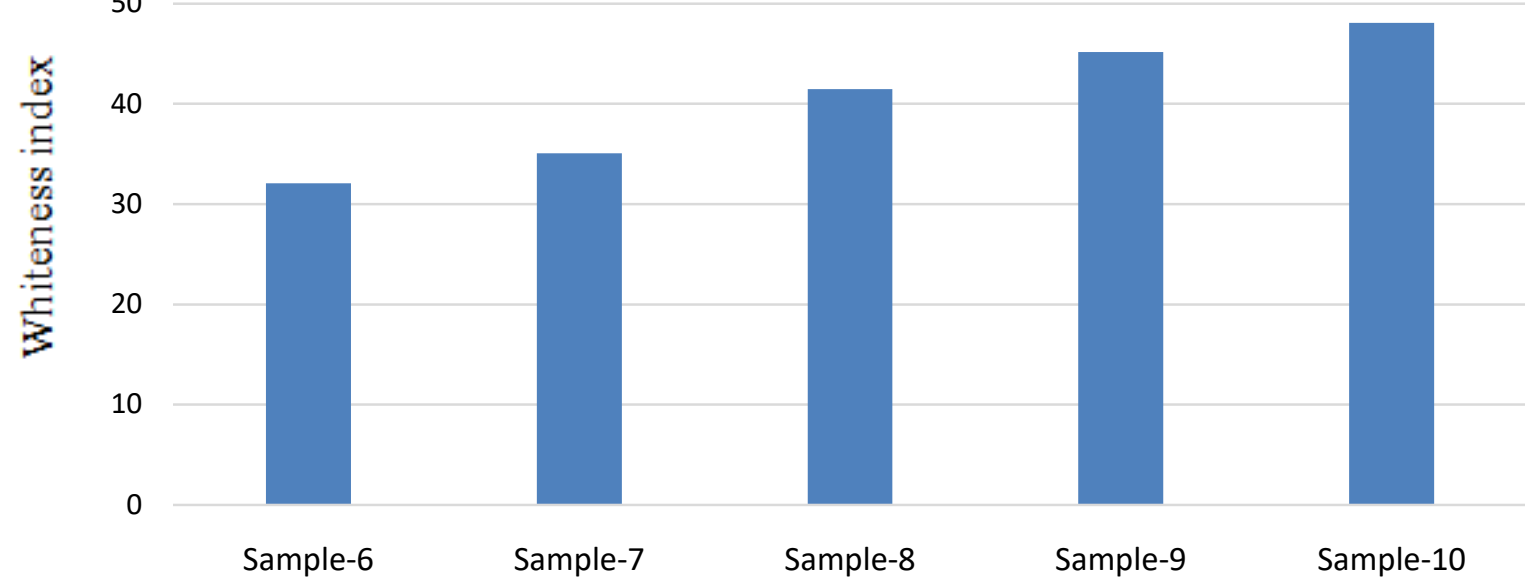

Figure 6: Effect of Sodium Hypochlorite (NaOCl) on whiteness

d) Effect of Sodium Hypochlorite ( $\mathrm{NaOCl}$ ) on bursting strength

Figure 7 shows that the bursting strength of the samples are almost same. 


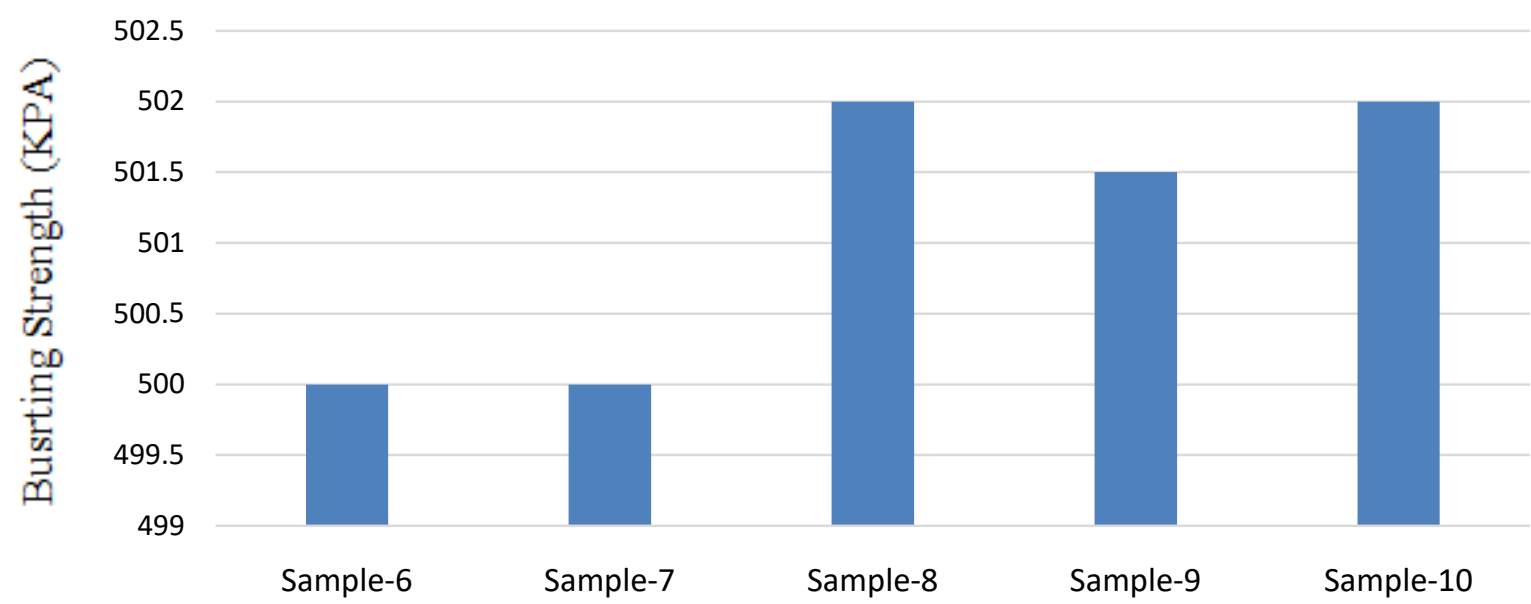

Figure 7: Effect of Sodium Hypochlorite (NaOCl) on bursting strength

e) Effect of Calcium Hypochlorite $\mathrm{Ca}(\mathrm{OCl})_{2}$ on whiteness

It is found that for increasing concentration of calcium hypochlorite, whiteness index is increased.

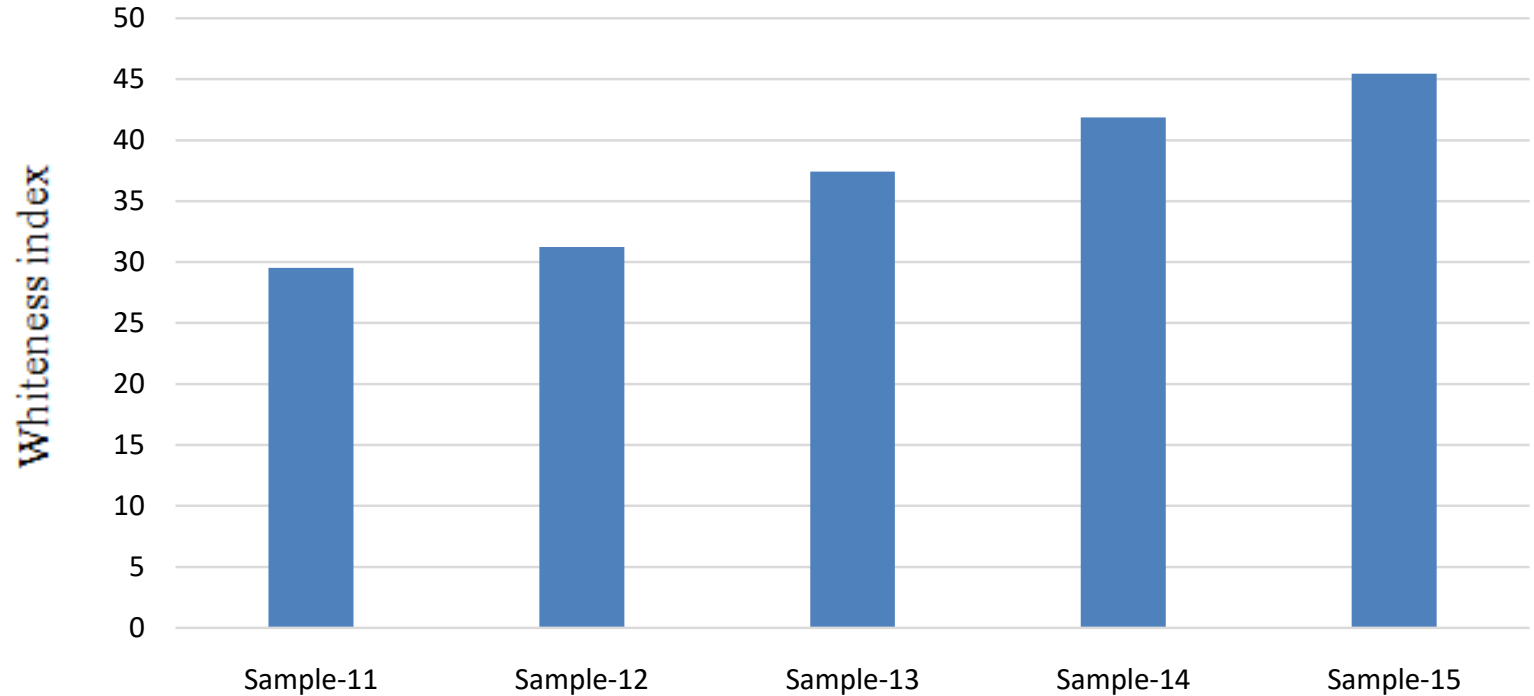

Figure 8: Effect of Calcium Hypochlorite $\mathrm{Ca}(\mathrm{OCl})_{2}$ on whiteness

f) Effect of Calcium Hypochlorite $\mathrm{Ca}(\mathrm{OCl})_{2}$ on bursting strength

The graph shows that for the higher concentration of calcium hypochlorite, bursting strength was less. At a concentration of $3.5 \mathrm{~g} / \mathrm{l}$ to $5.5 \mathrm{~g} / \mathrm{l}$ of Calcium Hypochlorite $\mathrm{Ca}(\mathrm{OCl})_{2}$ bursting strength are same. 


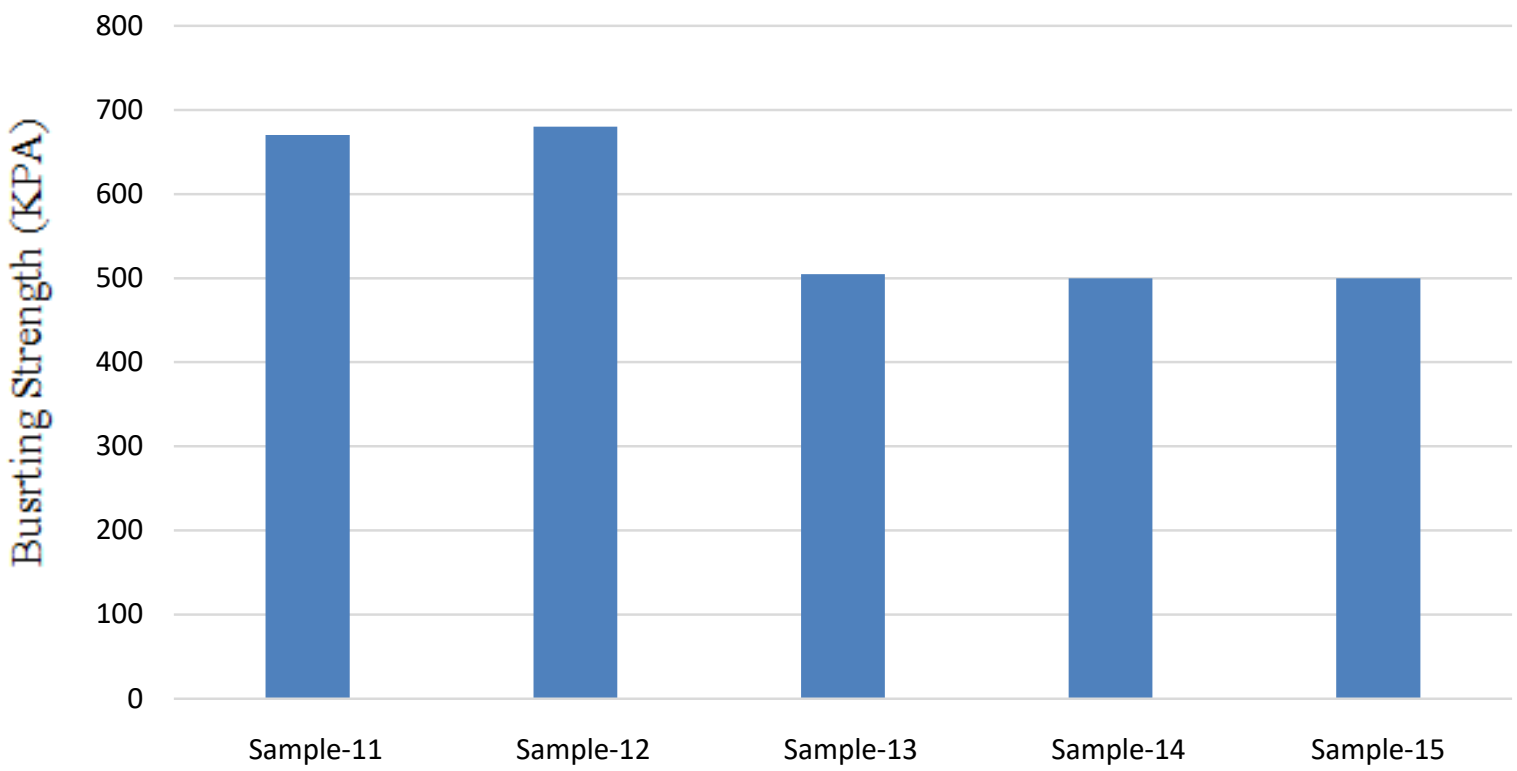

Figure 9: Effect of Calcium Hypochlorite $\mathrm{Ca}(\mathrm{OCl})_{2}$ on bursting strength

\section{Conclusion}

With the increase of the concentration of Hydrogen peroxide $\left(\mathrm{H}_{2} \mathrm{O}_{2}\right)$, Sodium Hypochlorite $(\mathrm{NaOCl})$, and Calcium Hypochlorite $\mathrm{Ca}(\mathrm{OCl})_{2}$, there is a significant improvement in the whiteness index of the bleached cotton fabric. When the concentration of Hydrogen peroxide $\left(\mathrm{H}_{2} \mathrm{O}_{2}\right)$, Sodium Hypochlorite ( $\mathrm{NaOCl})$ Calcium Hypochlorite $\mathrm{Ca}(\mathrm{OCl})_{2}$ was over $3.5 \mathrm{~g} / \mathrm{l}$, there was no remarkable change in whiteness. However, $4 \mathrm{~g} / \mathrm{l}$ concentration for Hydrogen peroxide $\left(\mathrm{H}_{2} \mathrm{O}_{2}\right)$, and $3.5 \mathrm{~g} / \mathrm{l}$ for Sodium Hypochlorite $(\mathrm{NaOCl})$, and Calcium Hypochlorite $\mathrm{Ca}(\mathrm{OCl})_{2}$, are the optimum concentration for suitable bleaching because though further increase in concentration, increases whiteness index but bursting strength of the cotton fabrics decreases due to hydrolyzation of cellulose.

\section{REFERENCES RÉFÉRENCES REFERENCIAS}

1. S. M. F. Kabir, M. I. Iqbal, P. P. Sikdar, M. M. Rahman and S. Akhter, - Optimizations of parameters of cotton fabric whiteness\|l, European Scientific Journal, vol. 10, no. 36, pp. 200-210, 2014.

2. E. R. Trotman, -Dyeing and chemical technology of textile fibres\|, Charles Griffin \& Co. Ltd, pp. 22, 1975.

3. https://www.ifatcc.org/wp-content/uploads/2018/01/ O19.pdf

4. D. Saravanan and T. Ramachandran, -Bleaching of cotton fabrics using hydrogen peroxide produced by glucose oxide sell, Indian Journal of Fibre \& Textile Research, vol. 35, pp. 281-283, 2010.

5. N. P. Sonaje and M. B. Chougule, -comparison of whiteness index of cotton fabric bleached with recycled waste water, International Journal of
Innovative Research in Science, Engineering and Technology, Vol. 2, Issue 8, pp. 3946-3951, 2013.

6. S. B. Abdul and G. Narendra, -Accelerated Bleaching of Cotton Material with Hydrogen Peroxidell, J Textile SciEng, vol. 3:140, doi:10.4172/2165-8064.1000140, 2013.

7. Naser, M. A. Haque, M. A. Islam, -optimization of bleaching parameters by whiteness index and bursting strength of knitted cotton fabric, International Journal of Science\& Technology, Vol. 4, Issue 4, pp. 40-43, 2015.

8. ISO 13938-2: 1999(en), Textiles-Bursting properties of fabrics - Part 2: Pneumatic method for determination of bursting strength and bursting distension. 